\title{
Outside-in, Inside-out, and Blended Marketing Strategy Approach: A Longitudinal Case Study
}

\author{
Moreno Frau ${ }^{1,2}$, Ludovica Moi ${ }^{1} \&$ Francesca Cabiddu ${ }^{1}$ \\ ${ }^{1}$ Department of Economics and Business, University of Cagliari, Cagliari, Italy \\ ${ }^{2}$ Corvinus Institute for Advanced Studies, Corvinus University of Budapest, Budapest, Hungary \\ Correspondence: Moreno Frau, Department of Economics and Business, University of Cagliari, IT, Viale \\ Sant'Ignazio, 74, 09123, Cagliari, Italy. E-mail: moreno.frau@unica.it
}

Received: May 7, 2020 Accepted: June 18, 2020 Online Published: June 23, 2020

doi:10.5539/ijms.v12n3p1 URL: https://doi.org/10.5539/ijms.v12n3p1

\begin{abstract}
Outside-in, inside-out, and blended marketing strategy perspectives represent an unbroken line of inquiry. Nonetheless, still few studies have empirically explored the distinctive characteristics of these three marketing strategy approaches. This study performs an in-depth retrospective longitudinal case study to explore how outside-in, inside-out, and blended marketing strategy approaches evolved. With this article, we enrich the marketing strategy debate by elucidating the in-depth features of the three approaches. This work also provides practitioners with a useful managerial diagnostic tool through which to identify firms' marketing strategy approach, and potential mismatches with the environment.
\end{abstract}

Keywords: outside-in, inside-out, blended approach, marketing strategy, longitudinal case study, qualitative research

\section{Introduction}

Since the early '90s, marketing scholars broadly discussed how marketing strategies facilitate enduring competitive advantage (e.g., Barney, 1991; Miller, Eisenstat, \& Foote, 2002; Russell, 1999; Srivastava, Shervani, \& Fahey, 1998). Marketing strategy development critically depends on a firm's internal resources as well as the external environment (Riezebos \& Van der Grinten, 2012; Ulrich \& Smallwood, 2007). In this conception, researchers are focused on two different schools of thought, namely, the inside-out and the outside-in strategy (Day \& Moorman, 2011; Miller et al., 2002). According to the outside-in approach, firms exploit the external inputs, such as customers, competitors, and suppliers (Tracey, Lim, \& Vonderembse, 2005) in addition to external knowledge (e.g., open innovation) (Carter, Grover, \& Thatcher, 2011; Saeed, Yousafzai, Paladino, \& De Luca, 2015; Frau et al., 2019) to adjust internal resources and capabilities and to fit environmental changes (Day \& Moorman, 2011). Conversely, according to the inside-out approach, firms leverage their dear, rare, unique, and irreplaceable internal resources to handle external occasions and menaces (Barney, 1991; Miller et al., 2002). Over time, these two perspectives have been trying to converge to push the boundaries of the single-taken approaches (Barney, 2014; Combs \& Ketchen Jr, 1999; Kozlenkova, Samaha, \& Palmatier, 2014; Makadok, 2001; Randall, Day, \& Moorman, 2013; Frau \& Cabiddu, 2016). As a result, a fresh outlook combining the benefits of both outside-in and inside-out approaches has emerged: the blended approach.

Despite the considerable body of knowledge on the three marketing strategy approaches (Day \& Moorman, 2011; Kozlenkova et al., 2014; Miller et al., 2002), little consideration has been dedicated to empirically examining their in-depth characteristics (e.g., Ordanini, Parasuraman, \& Rubera, 2014; Carter et al., 2011). The scant attention to empirical studies complicates the understanding of how to classify marketing theories and strategies according to the proper approach, as well as supporting practitioners in formulating effective marketing strategies.

Additionally, to our knowledge, no study has conducted a longitudinal analysis of the three approaches' evolution. Studies about the development of the marketing strategy approaches are significant for understanding how they operate and evolve.

This work has a two-fold objective: 1) to perform an in-depth analysis of the literature grasping the central and distinctive features of the three marketing strategy approaches (outside-in, inside-out, and blended), and organize 
them in a theoretical framework; 2) to empirically explore how the use of different marketing approaches have evolved. To this end, this paper attempts to answer the following research question: "How have firms been employing outside-in, inside-out, and blended approaches over time?"

Accordingly, this study adopts a retrospective longitudinal single-case study research design (Yin, 2008), focusing on the cooperative $3 \mathrm{~A}$ (Assegnatari Associati Arborea), a foremost dairy firm in Italy.

For research, this study contributes to extend current knowledge on marketing theory and strategy by displaying a dynamic succession of events linked to the marketing strategy characteristics, and suggesting a theoretical framework in which the key features of the three marketing strategy approaches are explained. For practice, this work provides managers with a useful foundation through which to adopt the proper marketing strategy approach that fits the external environment conditions.

Our study is organized as follows: first, we analyze the literature, and organize the key theoretical concepts in a theoretical framework; then, we describe the details of the methodology we adopted, and the data analysis process; finally, we argue about the findings, and end this work with the discussion section.

\section{Literature Review on Marketing Strategy Approaches}

Marketing scholars and professionals conceive marketing approaches as critical for developing strategy and reach competitive advantage (Srivastava et al., 2001; Kozlenkova et al., 2014). Firm's marketing approaches may exhibit as outside-in, inside-out, and blended.

Firms assume an outside-in perspective when they structure marketing strategy mainly considering the external environment dynamics (Baden-Fuller, 1995; Day \& Moorman, 2011; Lillis \& Lane, 2007). Therefore, it becomes crucial the monitoring of the whole external environment (D'Aveni, 1994; Chong, Bian, \& Zhang, 2016). For instance, customer monitoring allows gathering information on new market opportunities and customers' needs changes (Kohli \& Jaworski, 1990; Nakata \& Zhu, 2006), achieving superior performance and customer value (Day \& Moorman, 2011; Finne \& Grönroos, 2017). Whereas competitor monitoring facilitates the assessment of competitors' resources and capabilities, strengths, and weaknesses, to adjust strategies accordingly (Porter, 1985). Furthermore, supply-chain monitoring enables one to seize changes happening in suppliers and distributors (e.g., new materials or products) (Tracey et al., 2005; van Lakerveld \& van Tulder, 2017). While the monitoring of technological change fosters proactively seizing technological innovations in the industry relative to competitors (Carter et al., 2011). The monitoring of the external environment also includes the tracking of external knowledge outside the firm's borders and industry (March, Sproull, \& Tamuz, 1991; Morgan, Katsikeas, \& Appiah-Adu, 1998), to develop the market-based capabilities in absorbing and exploiting such knowledge (Barrales-Molina et al., 2014; Morgan et al., 1998).

The outside-in approach aims to provide external stakeholders satisfaction (e.g., customers, shareholders, suppliers, creditors) (Srivastava et al., 1998) to deliver valuable offerings in satisfying their needs (Holmemo, Rolfsen, \& Ingvaldsen, 2018; Ordanini et al., 2014; Schulz, Jonker, \& Faber, 2018). Hence, firms are required to develop proper market-based capabilities and assets (Barrales-Molina, Martínez-López, \& Gázquez-Abad, 2014; Conant, Mokwa, \& Varadarajan, 1990). Market-based capabilities (e.g., marketing expertise) gather market knowledge to adapt the firm to evolving markets (Ramaswami et al., 2009; Bruni \& Verona, 2009). They can be "distinctive" (Conant et al., 1990; Ngo \& O'Cass, 2012), as they are strictly related to the target market and enable to outpace competitors (Selznick, 2011), or even "dynamic", since they support other capabilities in accomplishing market evolution (Barrales-Molina et al., 2014; Morgan et al., 1998). On the contrary, market-based assets like channels, brands, reputation, and client portfolio, will mean any concrete, organization-related or individual characteristic that helps companies to elaborate and use approaches that boost productivity and performance on the market, while the benefits will be actualized in the market of the external product (Srivastava et al., 1998). They can be intangible, owing to a distinctive value challenging to imitate. According to the literature, the outside-in approach triggers demand-pull innovation and open innovation (Pérez, Dos Santos Paulino, \& Cambra-Fierro, 2017; Saeed et al., 2015; Slotegraaf \& Pauwels, 2008; Frau et al., 2019). In this perspective, the primary source of innovation is the customer demand (i.e., demand-pull), or the exploitation of external knowledge to improve internal innovation and extend outside firm's borders (i.e., open innovation) (Chesbrough, 2003; Yamin \& Kurt, 2018). Practical examples are technological, product/service, and process/activity innovation (Ferreira et al., 2015). Technological innovation refers to new tools or devices and includes better solutions for unique explicit or tacit market needs (Chidamber \& Kon, 1994). When firms deal with market changes, they innovate their products and services under customers' or stakeholders' inputs (Ordanini et al., 2014), and consequently alter their way of production and/or workers' assignment (product/service and process/activity innovation). 
Firms, taking advantage of internal company-specific property and capacity to mold their marketing strategies respectively, use an inside-out approach (Barney, 1991; Choi, 2016; Miller et al., 2002). For instance, the firm can exploit an internally-developed technology through R\&D to reduce production costs, and promote new marketing initiatives (e.g., launching a new product). A key characteristic of the inside-out approach is the internal efficiency, that is, the ability to profit from the relationship between its product and the required resources (Carter et al., 2011; Williamson, 1991), thereby enhancing the overall profitability. For instance, accuracy, flexibility, zero-defection strategy in production, delivery, and after-delivery are some of the practices aimed at improving internal efficiency and productivity (Ravald \& Grönroos, 1996). Internal efficiency can be broken up into resource, process, activity, and organizational efficiency. To increase the efficiency of a resource, the company seeks better practice for establishing and applying its tangible and intangible assets, and reduce costs to increase its revenue and avoid value co-destruction (Williamson, 1991; Cabiddu et al., 2019). The efficiency of activity and process indicates the actions and procedures that employees accomplished through their work.

While, the efficiency of the organization is a way a firm coordinates employee in groups and their hierarchical relationship (Carter et al., 2011). When referring to the inside-out approach, scholars highlight the resource endowment or the company's asset regarding resource quality (array and design) and quantity (Srivastava et al., 1998). Estimating the overall industry resource endowment, one could appreciate the rarity of a resource. As per the literature, the evolution of sustained competitive advantage relies, critically, on the supply endowment governed by a company (Barney, 1991, p. 116). Furthermore, the inside-out approach leverages on distinctive resources and capabilities (Bridson \& Evans, 2018; Teece et al., 1997). An asset is unique when it is owned by the company, or it seldom shows up is the respective industry. The company needs to implement a particular activity better than its competition to have a distinctive capability (Selznick, 2011).

Furthermore, companies, to pinpoint asymmetries with the competition, need to investigate their capabilities and assets (Miller et al., 2002). Because asymmetries are capabilities or assets that the firm owns, such asymmetries can be exploited as critical sources to create sustainable competitive advantage (Miller et al., 2002). Subsequently, the company can avoid being imitated by the competition, if it develops its distinctive capabilities and assets, and can set up a surface for turn into a firm that is more detectable, distinguishable, and relevant (Gromark \& Melin, 2013). Against this backdrop, the outside-in approach is taking care of the external stakeholders, whereas the inside-out approach tends the internal stakeholders' satisfaction (Aerts, Dooms, \& Haezendonck, 2015; Lillis \& Lane, 2007). The primary internal associates are firm owners, workers, and managers. Specifically, on the one hand, owners require repayment for their investments and a continuous increase in revenue rate in the long run. On the other hand, workers demand a reliable job and earning, enhancement in the work circumstances, and challenging tasks (Burmann, Hegner, \& Riley, 2009; Burmann, Jost-Benz, \& Riley, 2009) to grow and become a key employee in the firm (Lillis \& Lane, 2007). Finally, managers desire, e.g., to create high performing brands (Ulrich \& Smallwood, 2007). Differently from the outside-in approach, the inside-out one is a technology push approach (Jaakkola, Möller, Parvinen, Evanschitzky, \& Mühlbacher, 2010), which means that the firm urges launching into the market a technological innovation prepared by its internal crew (e.g., R\&D), disrespecting the fact that the innovation is not demanded by its customers. Additionally, the inside-out approach strongly focuses on the strategies based on the internal knowledge (Nonaka, Toyama, \& Konno, 2000), developed and shared within the firm borders and in particular by the employees (Spender, 1996), including not only the R\&D unit associates but also the others involved in the knowledge-producing.

As mentioned before, although the inside-out and outside-in approaches appear to be each other's opponents, a joined use of them has been currently a new point of view in the academic debate (Barney, 2014; Saeed, Yousafzai, Paladino, \& De Luca, 2015; Srivastava, Fahey, \& Christensen, 2001; Frau \& Cabiddu, 2016). The result is the emergence of the blended approach, a new approach that merges conveniences of both the outside-in and inside-out aspects. Researchers developed the blended approach to explain accurately the relation among a company's performance, its resource, and its external environment (Kornum, Gyrd-Jones, Al Zagir, \& Brandis, 2017; Kozlenkova et al., 2014; Day, 2014). Meanwhile, a blended aspect of marketing strategy approaches has been developed by practitioners to exploit both approaches (Gellweiler, 2018; Humbert et al., 1997; Urde et al., 2013). The blended approach considered the spanning capabilities (Day, 1994), that are, the arrangement of actions that includes the processes applied to fulfill the foreseen customer needs defined by the outside-in opportunities and meet the expectations previously set to boost relationships (Day, 1994). Hence, spanning capabilities can build connections between inside-out and outside-in capabilities to allow the collective function of the two approaches. Therefore, spanning capabilities can create links and connections between outside-in and 
inside-out capabilities to make them working together (Conduit, Matanda, \& Mavondo, 2014; Qiu, 2012). Accordingly, they help to develop distinctive capabilities that are difficult to imitate by competitors. The blended approach also involves interfirm cooperation (Combs \& Ketchen, 1999), which concerns partnerships between two or more organizations, or the organization and its customers. When a firm decides to cooperate with other firms or its customers, it usually aims to cut or split expenditures and enhance internal efficiency (Carter et al., 2011; Williamson, 1991).

The results of our literature analysis are synthesized in a theoretical framework, in which the key features of the three marketing strategy approaches are depicted (see Figure 1). Drawing on our framework, we then proceeded by empirically exploring the three marketing strategy approaches through a retrospect longitudinal single-case study.

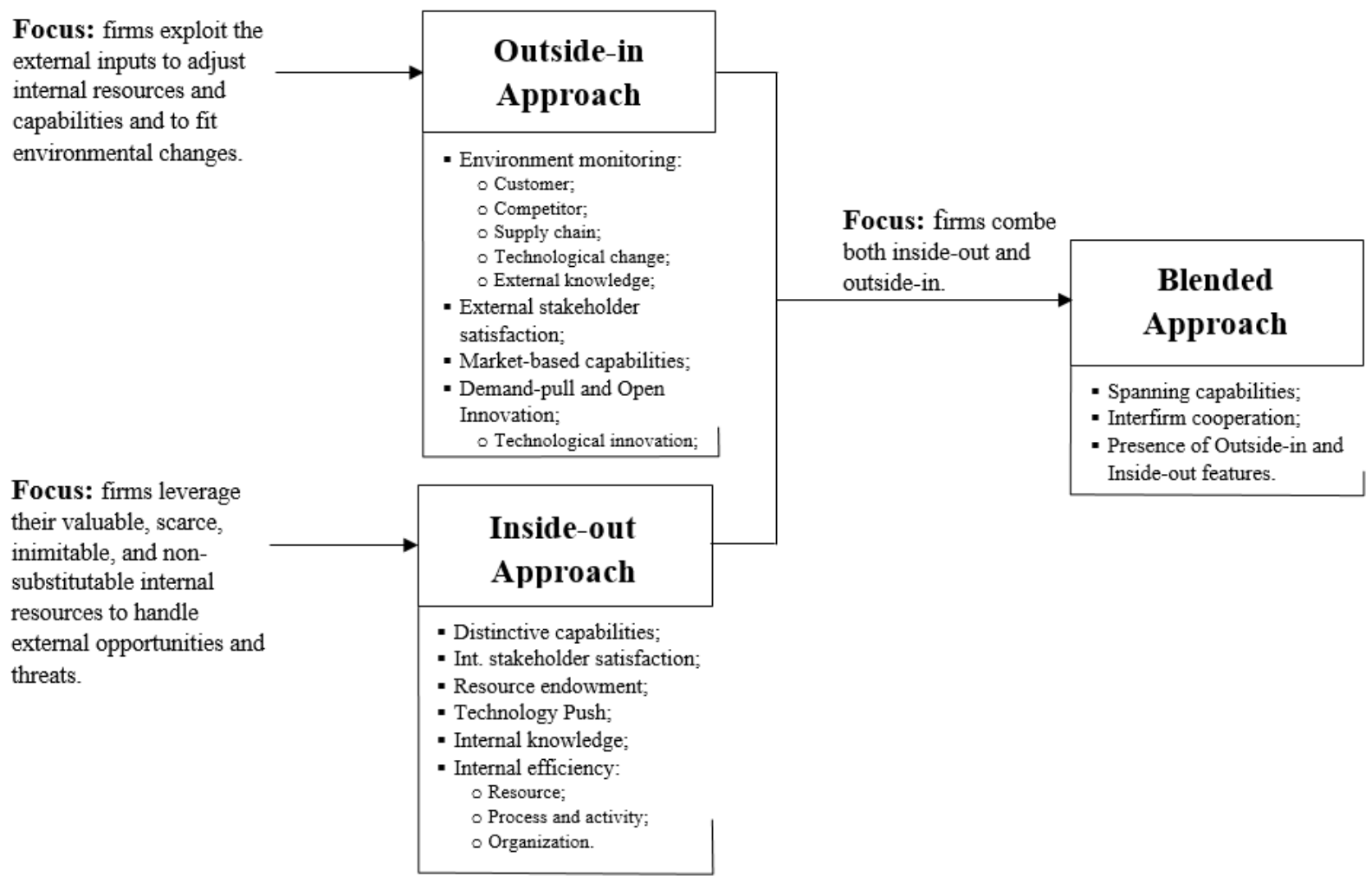

Figure 1. The theoretical framework of marketing strategy approaches.

\section{Methodology}

This study employs a qualitative retrospect longitudinal single-case study, which is suitable for "how" modes of inquiry about a set of events (Yin, 2008).

The longitudinal research design increases the validity of this work as it allows the investigation of complex multi-variable phenomena unfolding constantly (Eisenhardt, 1989). The analysis covers the period from 1956 (company foundation date) to April 2020.

\subsection{Case Selection Process}

We selected our case-study applying these selection principles: 1) transparency; 2) access to important information; 3) good background information base of the company and of its surroundings (customers, work routine, habits, associates, production organization, and standards of excellence); 4) long-running company; 5) medium or big size company; 6) a wide range of products which includes at least a product developed from customers' needs.

Access to important information, clarity, and solid background information base of the company ensure access to proper data quality, which is fundamental for qualitative research design. Moreover, the firm should implement all the three approaches, so that the ideal company exists for a minimum of fifteen years because a marketing 
strategy needs leastwise five years to be accurately carried out. Apart from longevity, the company requires to expand in size. The ideal firm also needs a well-structured marketing unit. Furthermore, the marketing unit should have worked with an ample range of products. A large variety of products allows studying marketing strategies related to the product created from different inputs, for example, from the firm's specific resources or unique production process, as well as from consumers and other external stakeholders' needs. Finally, we selected a case study that can probably develop the current theory (Eisenhardt, 1989).

Based on the criteria mentioned above, it was chosen the firm 3A (Assegnatari Associati Arborea), which is a noted dairy cooperative of firms on the Sardinian market (Italy). A cornerstone element of 3A's business is Latte Arborea, its top brand. The firm was founded in 1956, and it performs consolidated marketing activity. 3A solidly keeps pace with times and market needs. Hence it develops an ample assortment of products. Apart from a variety of dairy products, such as curd and ripened cheese, milk, yogurt, mozzarella, and the most recent ice-cream mix, 3A has also started selling a full line lactose-free product on the market, and even an innovational product named WEY explicitly developed for sportspersons use.

\subsection{Data Collection}

We gathered data from several sources: semi-structured interviews, the firm's social media profiles, its official website, internal reports, and documentation. We triangulated data sources to generate more robust findings (Eisenhardt, 1989; Yin, 2008).

We collected primary data through semi-structured interviews with key respondents. We followed a semi-structured interview protocol including fifteen open-ended questions (e.g., "Over time, how your business adjusts the way it engages the customers?", "What is that make your business inimitable in comparison with its competitors and why?" "How your company collaborate with other organizations and to which purpose?") (Fontana \& Frey, 2000). The protocol was pilot-tested to verify the clarity of questions and refined based on the feedback received (Yin, 2008).

We stopped at 8 interviews when theoretical saturation was reached. The interviews lasted between 50 and 90 minutes (see Table 1).

Table 1. List of informants and interview duration

\begin{tabular}{ll}
\hline Informant & Interview length \\
\hline Milk Category Manager & 61 \\
Dairy Product Category Manager & 82 \\
Head of Marketing & 57 \\
Board Chairman & 65 \\
CEO & 73 \\
Production Manager & 90 \\
Head of IT & 50 \\
Head of R\&D & 84 \\
\hline
\end{tabular}

We collected secondary data through social networks, the official website, and internal documents. We included the Latte Arborea Facebook page and YouTube channel as the contents are precisely dated and, hence, suitable for a retrospective longitudinal analysis. We employed NCapture, an NVivo's browser tool, to gather the data from the firm's official website and the materials shared by Latte Arborea (e.g., posts, tags, pictures, videos, links), and the firm's responses to customers' comments. We also included in the analysis advertising video published on the firm's YouTube channel.

\subsection{Data Analysis}

We structured data according to the theoretical framework depicted in Figure 1. We followed a concept-driven coding scheme based on three primary nodes outside-in, inside-out, and blended approach, and nineteen child-nodes, which embody the features of the three approaches (e.g., environment monitoring, internal efficiency, resource endowment). Finally, we used additional child-nodes representing the sub-characteristics (e.g., competitor monitoring, technological innovation, resource efficiency) (Gibbs, 2007). Furthermore, the attribute "time" was added to nodes and child-nodes to keep track of time during the data analysis accurately and adequately.

To check the consistency among practice and theory, each code was compared with the features and sub-features' definitions given in the literature section. 
The coding activities were performed separately and simultaneously by two of the co-authors. We checked and validated reliability by running a Coding Comparison Query (coefficient $\mathrm{K}$ was above 0.75 ).

Finally, we run a matrix query based on the attribute "time" to show the nodes with their contents in chronologic order.

\section{Findings}

According to data analysis, we distinguished three main periods during which different marketing strategy approaches prevailed: inside-out (1956-1985); outside-in (1986-2009); blended approach (2010-2020).

By performing an event-ordered matrix (Miles and Huberman 1994), this study tried to link the events relevant for the firm marketing strategy with each of the three periods (see Table 2).

Table 2. Event-ordered matrix: dominant marketing strategy approach evolution.

\begin{tabular}{|c|c|c|c|c|c|c|}
\hline \multicolumn{2}{|c|}{ Theoretical framework } & \multicolumn{2}{|r|}{ Periods } & $\begin{array}{l}\mathrm{T}_{1} \\
1956-1985\end{array}$ & $\begin{array}{l}T_{2} \\
1986-2009\end{array}$ & $\begin{array}{l}\mathrm{T}_{3} \\
2010-2020\end{array}$ \\
\hline \multirow[t]{10}{*}{$\begin{array}{l}\text { Blended } \\
\text { Approach }\end{array}$} & Inside-out & Resource end & ment & $\begin{array}{l}\quad \text { Purchase of the } \\
\text { production plant; } \\
\text { - Purchase of the tank } \\
\text { trucks; } \\
\text { - Investments in } \\
\text { production plant development. }\end{array}$ & & \\
\hline & & Distinctive as & $\mathrm{s}$ and capabilities & & & $\begin{array}{l}\text { - Connection with } \\
\text { the territory. }\end{array}$ \\
\hline & & Internal stakel & der satisfaction & $\begin{array}{l}\text { - } \quad \text { Growth in market share; } \\
\text { - } \quad \text { Demand exceeds supply. }\end{array}$ & & \\
\hline & & Technology p & 1 & $\begin{array}{l}\text { - Milk distributed in } \\
\text { triangular cartons rather than in } \\
\text { bulk; } \\
\text { triangular package to a liter } \\
\text { rectangular one. }\end{array}$ & & \\
\hline & & Internal know & & $\begin{array}{l}\text { The launch in the market } \\
\text { of a new type of cheese. }\end{array}$ & & \\
\hline & & $\begin{array}{l}\text { Internal } \\
\text { efficiency }\end{array}$ & $\begin{array}{l}\text { Resource } \\
\text { efficiency }\end{array}$ & - Cows nutrition care. & & $\begin{array}{l}\text { - Production } \\
\text { involves using } \\
\text { secondary outputs in } \\
\text { other processes. }\end{array}$ \\
\hline & & & $\begin{array}{l}\text { Process and } \\
\text { activity efficiency } \\
\text { Organizational } \\
\text { efficiency }\end{array}$ & $\begin{array}{l}-\quad \text { Breeding farm } \\
\text { rationalization. } \\
\text { - } \quad \text { Breeding farm } \\
\text { modernizing; } \\
\text { - Investments in quality } \\
\text { improvement. }\end{array}$ & & \\
\hline & Spanning C & bilities & & & & $\begin{array}{l}\text { - Change of } \\
\text { corporate image } \\
\text { leveraging on quality, } \\
\text { link with the territory } \\
\text { and customer } \\
\text { satisfaction; } \\
\text { - Settlement of } \\
\text { R\&D function. }\end{array}$ \\
\hline & Interfirm C & eration & & & & $\begin{array}{l}-\quad \text { Cooperative ties } \\
\text { with suppliers. }\end{array}$ \\
\hline & Outside-in & $\begin{array}{l}\text { Demand-pull } \\
\text { and open } \\
\text { innovation }\end{array}$ & $\begin{array}{l}\text { Technological } \\
\text { innovation } \\
\text { Product and } \\
\text { process } \\
\text { innovation }\end{array}$ & & $\begin{array}{l}\text { - Technologies } \\
\text { developed by suppliers. } \\
\text { - Launch in the } \\
\text { market of products } \\
\text { inspired by customer } \\
\text { needs. }\end{array}$ & $\begin{array}{l}\text { - Further launch } \\
\text { of new products } \\
\text { inspired by customer } \\
\text { requirement }\end{array}$ \\
\hline
\end{tabular}


External stakeholder satisfaction

Market-based capabilities and assets

$\begin{array}{ll}\begin{array}{l}\text { Environment } \\ \text { monitoring }\end{array} & \begin{array}{l}\text { Customer } \\ \text { monitoring }\end{array} \\ & \begin{array}{l}\text { Competitor } \\ \text { monitoring }\end{array} \\ & \\ & \text { Supply chain } \\ & \begin{array}{l}\text { Technological } \\ \text { change } \\ \text { monitoring }\end{array} \\ \text { External } \\ \text { knowledge } \\ \text { monitoring }\end{array}$

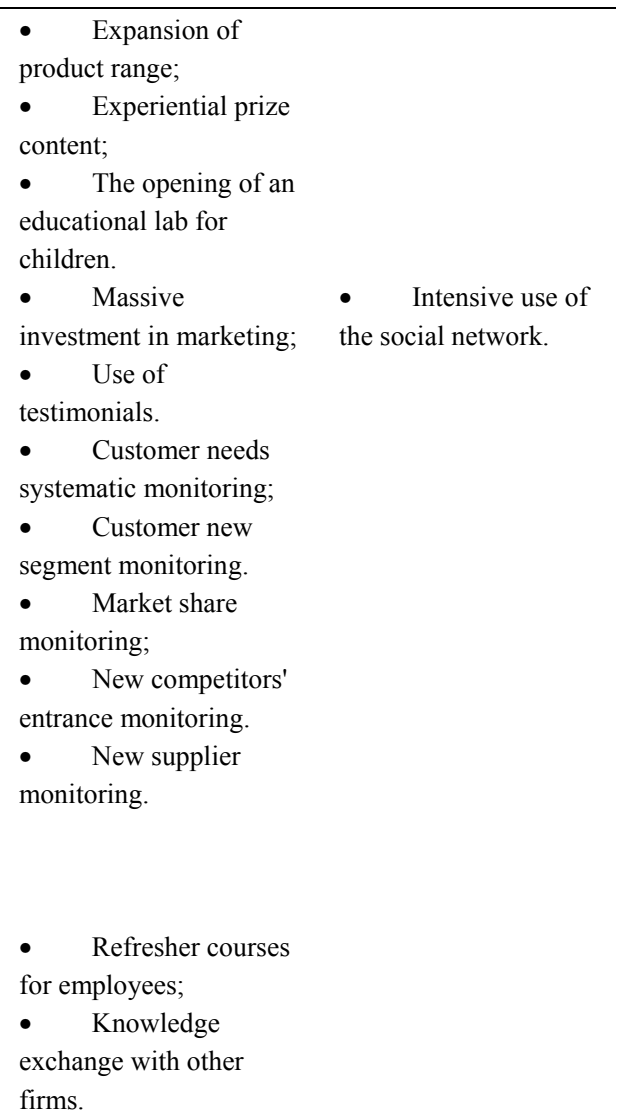

\subsection{Inside-out Approach (T1 1956-1985)}

The use of the Inside-out approach (T1) started when the cooperative 3A was founded (1956). The firm formally began its activities when it purchased the production plant and created the brand "Latte Arborea". Even if it was early to observe a well-structured marketing unit, some marketing tasks were already visible. A Facebook post backdated in the year 1956 claims, "Cooperative $3 A$ was founded to directly sell the products obtained from milk processing provided by partners ' manufacturers". The strategy is explicit: the direct sale of partners' products. In doing so, Latte Arborea bought tank trucks, and invested in the production plant extension (resource endowment, Table 2).

Over time, Latte Arborea tried to extend its size, looking for new production processes (internal efficiency), new packages (technology push), and new products (internal knowledge). About internal efficiency, the firm started a program of rationalization for the breeding farms to reduce costs. At the same time, it worked hard to improve milk production, taking care of cows' nutrition, modernizing breeding farms, and investing in milk quality. One of the first advertisement broadcasted on regional TV stations and accessible on the YouTube channel, says: "We are brought together by genuineness (strict screening of animal feed), by the care to animals' health (supervision of the cow's well-being), and by the willingness to raise the welfare of everyone".

According to the firm website, in 1966, 3A introduced a new way to supply milk, which is "no longer sold in bulk, but in triangular cartons" (technology push). This event represents a milestone in the firm's inside-out marketing strategy as it triggered the change in customers' habits. The firm's internal resources and capabilities were strong enough to change its market. Another step in the same direction is the introduction of a new product, a crud cheese. Latte Arborea's customer used to consume aged pecorino cheese when the firm launched a crud cow cheese produced thanks to internal knowledge. This new product managed to change customers' tastes. Finally, according to Latte Arborea's official Facebook page and website, the outside-in marketing strategy contributed to internal stakeholder satisfaction since "Latte Arborea starts penetrating throughout the island [its market] slowly undermining the monopoly of sheep's milk".

\subsection{Outside-in Approach (T2 1986-2009)}

The use of the Outside-in approach (T2) began in 1986 when the company made a massive investment in marketing, which ended in 2009 when Latte Arborea decided to restyle its image. During T2, the firm intensely 
focused on its market and its external environment (Table 2).

Latte Arborea started creating products inspired by customer needs. For example, "the lactose-free milk has been developed thanks to an input coming from the market," claimed the milk category manager. The development of a high digestibility product line, conceived to lactose intolerance people, manifested Latte Arborea's willingness to welcome new ideas from the market (pull innovation).

Regarding the environment monitoring, to keep customers' satisfaction controlled, "We conduct an annual survey [...] to measure the brand health status... this on the consumer side, market," said the dairy product category manager. The production manager added that also competitors are monitored: "Certain countries are big milk producers, and can cause fluctuations in the price [...] this brings market changes, consequently, significant implications in marketing strategies". In other words, Latte Arborea catches information about the external environment to be proactive to market changes. Also, the firm pushes key workers to improve themselves by cross-pollinating their knowledge with others: "exploiting the chances provided by the firm to meet other people, to compare ourselves with other companies' employees, to strengthen our skills, and see what occurs in other businesses, we develop the capability to transfer the knowledge gained in these experiences on the tasks that we do in our firm," claimed the CEO.

Furthermore, even a closed observation of the supply chain matters: "Our company handles and inspects the entire supply chain," said the board chairman. The firm has a market share distinguished by certified quality, that in turn is based on a high performing supply chain. As regards the external stakeholder satisfaction, Latte Arborea expanded its product range and, simultaneously, launched contents with an experiential prize such as holidays or tickets for sport and music events.

Data showed that, during T2, Latte Arborea adapted itself to market changes, using innovation-based marketing strategies as inputs for the new product development, process/operation adjustments, and technology changes. In line with the outside-in approach, the firm changed capabilities and assets internally developed to match with its market and, more in general, with its external environment.

\subsection{Blended Approach (T3 2010-2020)}

T3 started at the beginning of 2010 when $3 \mathrm{~A}$ decided to restyle its image. It keeps going on, but the dataset ends in April 2020. During T3, the firm focused on both its internal resources and capabilities and its market and external environment at once, trying to balance both (Table 2). In this attempt, spanning capabilities played a crucial role. In 2010, the firm started to grow and conquer new market shares in Italy as well as exporting its products in international markets. For this reason, the firm radically redesigned its image and re-mold its brand. The firm changed its payoff to "The cows' happy island" from "milk from Sardinian breeding of cows only," claimed the head of marketing. The new one introduces animal welfare and gives emphasis to a surprising element: the breeding of cows can thrive in a Mediterranean climate too, which is "an element that amazes and attracts customers", revealed an internal report base on a survey. Thus, the presence of cows in Sardinia is a fact that astonishes and catches new customers, and it has converted as the Latte Arborea distinguishing component. Additionally, the role played by Research and Development has been changing. The head of R\&D said: "people who work in our office are rising their importance because $R \& D$ is becoming the link among production, suppliers, marketing, and trade". Therefore, the company is trying to create links between inside-out oriented functions like production with marketing and trade (inside-out).

Regarding interfirm cooperation, we found in the dataset that partnerships are essential, and a source of advantage: "Without cooperation... it would be hard! Partnerships are vital to business growth... also when cooperation is between firms from different industries, the exchange of knowledge is every time positive. Our company might not be successful without collaboration", revealed the head of IT. Finally, Latte Arborea combined product innovation and resource efficiency by developing products such as WEY, based on secondary outputs from other production processes. Such products can improve company efficiency by reducing production waste and attracting new market segments (e.g., athletes).

To sum up, when the firm was founded, customers' needs were essential, and the demand was enough to absorb the production. Therefore, $3 \mathrm{~A}$ focused on internal processes and exploited its internal resources and capabilities to change market habits (inside-out 1956-1985). When the market became more competitive, Latte Arborea changed entirely its marketing strategy approach focusing on customer's needs and monitoring its external environment. This time, Latte Arborea changed itself to fit with the environment (outside-in 1986-2009). When the company decided to expand its market to the national and international contexts, it changed its marketing strategy approach again, paying the same attention to the external as well as to the internal dynamics (blended approach 2009-2020). 


\section{Discussion and Theoretical Contribution}

This study provides useful theoretical and empirical contributions to the literature on marketing theory and strategy research.

Although previous literature offers a considerable body of knowledge on outside-in, inside-out and blended marketing strategy approaches (Barney, 2014; Combs \& Ketchen, 1999; Conduit et al., 2014; Kozlenkova et al., 2014; Makadok, 2001; Randall et al., 2013; Chong et al., 2016), little attention was devoted to an in-depth understanding on their main distinctive characteristics. By extending prior literature, this work advances a theoretical framework in which the key features of the three marketing strategy approaches are explained.

Specifically, this paper analyzed previous literature to design a theoretical framework and performed a retrospective longitudinal empirical study to empirically validate the framework and explore the evolution of the marketing strategy approaches over time. To accomplish these results, the development of this work tried to fulfill two aims: firstly, this research identified and described the main features of three marketing strategies (outside-in, inside-out and blended), and organized them in the theoretical framework depicted in Figure 1; secondly, our research contributes to the marketing strategy discussion by providing an empirical qualitative longitudinal study. That is why our article provides relevant implications for theory and practice.

Furthermore, there is still a lack of empirical studies on the topic (Kozlenkova et al., 2014; Day, 2014). While previous empirical studies focused on different geographical context or industries, looking for the influence of these factors on marketing strategy approaches (Urde et al., 2013; Jaakkola et al., 2010), few studies have analyzed the evolution of these strategies along the time. Thanks to the retrospective longitudinal case-study conducted in this article, we provide empirical evidence about the progressive and dynamic succession of events linked to marketing strategy characteristics (Table 2). The facts are shown in a chronological vein. The double connection with features and time allows us to identify the evolution of marketing strategy approaches over time.

We acknowledge that this article is subject to some limitations. The qualitative data analysis relies on data gathered from a single-case study. Although our findings could be generalized to a certain degree, this work offers an initial framework of analysis. Further research is needed to extend our knowledge to other contexts and a larger sample. Therefore, we encourage future empirical validation and testing of our framework.

\subsection{Managerial Implications}

This paper may raise management's awareness about the "style" adopted in formulating and implementing their strategies of marketing, by defining the main features of the three approaches. Practitioners should be trained to recognize the features of the marketing strategy and understand whether the marketing strategy is coherent with the firm's global strategy to avoid internal divergence in strategic planning.

The distinction of the characteristics of the three approaches would help during marketing strategy formation since it leads to a more informed marketing plan development. Furthermore, the framework can also be used during the resource allocation process to decide the destination of financial resources, e.g., if they should be placed according to an outside-in perspective, an inside-out perspective, or a blended perspective. Moreover, training marketing managers in recognizing the main characteristics of the marketing strategy, would facilitate the identification of competitors' strategies, and provide information to feed a strategic countermove.

This study could serve as a useful foundation for practitioners to orient themselves across different approaches. Thus, if the company wanted to change its marketing strategy approach, this study would facilitate decision-making. It also could help a more efficient acknowledgment of marketing goals.

Lastly, this work may increase managers' consciousness of the advantages of the blended strategy, that could be utilized to exploit internal resources and external inputs at once. This means that the blended approach could help exceed the restrictions of the strategies individually-considered, combining the benefits of both the inside-out and outside-in approaches.

\section{Acknowledgments}

The authors gratefully acknowledge the Sardinian Regional Government for the financial support. Also, Moreno Frau thanks the CIAS (Corvinus Institute for Advanced Studies) for funding his current position as visiting research fellow at the Corvinus University of Budapest.

\section{References}

Aerts, G., Dooms, M., \& Haezendonck, E. (2015). Stakeholder management practices found in landlord seaport authorities in Flanders: an inside-out perspective. International Journal of Shipping and Transport Logistics, 7(5), 597-620. https://doi.org/10.1504/IJSTL.2015.072019 
Baden-Fuller, C. (1995). Strategic innovation, corporate entrepreneurship, and matching outside-in to inside-out approaches to strategy research. British Journal of Management, 6(s1), S3-S16. https://doi.org/10.1111/j.1467-8551.1995.tb00134.x

Barney, J. (1991). Firm resources and sustained competitive advantage. Journal of Management, 17(1), 99-120. https://doi.org/10.1177/014920639101700108

Barney, J. B. (2014). How marketing scholars might help address issues in resource-based theory. Journal of the Academy of Marketing Science, 42(1), 24-26. https://doi.org/10.1007/s11747-013-0351-8

Barrales-Molina, V., Martínez-López, F. J., \& Gázquez-Abad, J. C. (2014). Dynamic marketing capabilities: Toward an integrative framework. International Journal of Management Reviews, 16(4), 397-416. https://doi.org/10.1111/ijmr.12026

Bridson, K. C., \& Evans, J. (2018). Brand compass: charting a course to improve firm performance. Journal of Strategic Marketing, 26(2), 174-187. https://doi.org/10.1080/0965254X.2016.1195861

Bruhn, M., \& Schnebelen, S. (2017). Integrated marketing communication-from an instrumental to a customer-centric perspective. European Journal of Marketing, 51(3), 464-489. https://doi.org/10.1108/EJM-08-2015-0591

Bruni, D. S., \& Verona, G. (2009). Dynamic marketing capabilities in Science - based firms: An exploratory investigation of the pharmaceutical industry. British Journal of Management, 20(1), 101-117. https://doi.org/10.1111/j.1467-8551.2008.00615.x

Burmann, C., Hegner, S., \& Riley, N. (2009). Towards an identity-based branding. Marketing Theory, 9(1), 113-118. https://doi.org/10.1177/1470593108100065

Burmann, C., Jost-Benz, M., \& Riley, N. (2009). Towards an identity-based brand equity model. Journal of Business Research, 62(3), 390-397. https://doi.org/10.1016/j.jbusres.2008.06.009

Cabiddu, F., Moreno, F., \& Sebastiano, L. (2019). Toxic collaborations: co-destroying value in the B2B context. Journal of Service Research, 22(3), 241-255. https://doi.org/10.1177/1094670519835311

Carter, M., Grover, V., \& Thatcher, J. B. (2011). The emerging CIO role of business technology strategist. MIS Quarterly Executive, 10(1), 19-29.

Chesbrough, H. (2003). The logic of open innovation: managing intellectual property. California Management Review, 45(3), 33-58. https://doi.org/10.1177/000812560304500301

Chidamber, S. R., \& Kon, H. B. (1994). A research retrospective of innovation inception and success: the technology-push, demand-pull question. International Journal of Technology Management, 9(1), 94-112.

Choi, S. (2016). An inside-out marketing strategy for innovation among human service nonprofits in south Korea. Nonprofit Management and Leadership, 26(3), 331-347. https://doi.org/10.1002/nml.21196

Chong, W. K., Bian, D., \& Zhang, N. (2016). E-marketing services and e-marketing performance: the roles of innovation, knowledge complexity and environmental turbulence in influencing the relationship. Journal of Marketing Management, 32(1-2), 149-178. https://doi.org/10.1080/0267257X.2015.1102758

Combs, J. G., \& Ketchen Jr, D. J. (1999). Explaining interfirm cooperation and performance: toward a reconciliation of predictions from the resource-based view and organizational economics. Strategic Management Journal, 867-888. https://doi.org/10.1002/(SICI)1097-0266(199909)20:9<867::AID-SMJ55>3.0.CO;2-6

Conant, J. S., Mokwa, M. P., \& Varadarajan, P. R. (1990). Strategic types, distinctive marketing competencies and organizational performance: a multiple measures-based study. Strategic Management Journal, 11(5), 365-383. https://doi.org/10.1002/smj.4250110504

Conduit, J., Matanda, M. J., \& Mavondo, F. T. (2014). Balancing the act: the implications of jointly pursuing internal customer orientation and external customer orientation. Journal of Marketing Management, 30(13-14), 1320-1352. https://doi.org/10.1080/0267257X.2014.909513

D'Aveni, A. D. (1994). Hypercompetition: Managing the dynamics of strategic maneuvering. New York: WirtschaftsWoche.

Day, G. S. (1994). The capabilities of market-driven organizations. The Journal of Marketing, 37-52. https://doi.org/10.1177/002224299405800404

Day, G. S. (2014). An outside-in approach to resource-based theories. Journal of the Academy of Marketing 
Science, 42(1), 27-28. https://doi.org/10.1007/s11747-013-0348-3

Day, G. S., \& Moorman, C. (2011). An outside-in perspective to strategy-step outside to see what's important. Marketing Management, 20(3), 22.

Eisenhardt, K. M. (1989). Building theories from case study research. Academy of Management Review, 14(4), 532-550. https://doi.org/10.5465/amr.1989.4308385

Ferreira, J. J., Fernandes, C. I., Alves, H., \& Raposo, M. L. (2015). Drivers of innovation strategies: Testing the Tidd and Bessant (2009) model. Journal of Business Research, 68(7), 1395-1403. https://doi.org/10.1016/j.jbusres.2015.01.021

Finne, A., \& Grönroos, C. (2017). Communication-in-use: customer-integrated marketing communication. European Journal of Marketing, 51(3), 445-463. https://doi.org/10.1108/EJM-08-2015-0553

Fontana, A., \& Frey, J. H. (2000). The interview: From structured questions to negotiated text. Handbook of Qualitative Research, 2(6), 645-672.

Frau, M., \& Cabiddu, F. (2016). Exploring the Traits of Marketing Strategy Approaches: The Latte Arborea Case Study. International Conference on Marketing and Business Development Journal, 2(1), 43-60.

Frau, M., Moi, L., Angioni, E., \& Cabiddu, F. (2019). How open innovation shapes strategy: an explorative multiple case study in the ICT industry. Sinergie Italian Journal of Management, 37(1), 217-240. https://doi.org/10.7433/s108.2019.12

Gellweiler, C. (2018). Cohesion of RBV and industry view for competitive positioning. thematic fields. Strategic Management, 23(2), 3-12. https://doi.org/10.5937/StraMan1802003G

Gibbs, G. R. (2007). Thematic coding and categorizing. Analyzing Qualitative Data (pp. 38-56). London: Sage. https://doi.org/10.4135/9781849208574.n4

Gromark, J., \& Melin, F. (2013). From market orientation to brand orientation in the public sector. Journal of Marketing Management, 29(9-10), 1099-1123. https://doi.org/10.1080/0267257X.2013.812134

Holmemo, M. D.-Q., Rolfsen, M., \& Ingvaldsen, J. A. (2018). Lean thinking: Outside-in, bottom-up? The paradox of contemporary soft lean and consultant-driven lean implementation. Total Quality Management \& Business Excellence, 29(1-2), 148-160. https://doi.org/10.1080/14783363.2016.1171705

Huber, G. (1985). Temporal stability and response-order biases in participant descriptions of organizational decisions. Academy of Management Journal, 28(4), 943-950. https://doi.org/10.5465/256247

Humbert, M., Jolly, D., \& Thérin, F. (1997). Building strategy on technological resources and commercial proactiveness: the Gemplus case. European Management Journal, 15(6), 658-666. https://doi.org/10.1016/S0263-2373(97)00049-2

Jaakkola, M., Möller, K., Parvinen, P., Evanschitzky, H., \& Mühlbacher, H. (2010). Strategic marketing and business performance: A study in three European "engineering countries." Industrial Marketing Management, 39(8), 1300-1310. https://doi.org/10.1016/j.indmarman.2010.06.005

Kohli, A. K., \& Jaworski, B. J. (1990). Market orientation: the construct, research propositions, and managerial implications. The Journal of Marketing, 1-18. https://doi.org/10.1177/002224299005400201

Kornum, N., Gyrd-Jones, R., Al Zagir, N., \& Brandis, K. A. (2017). Interplay between intended brand identity and identities in a Nike related brand community: Co-existing synergies and tensions in a nested system. Journal of Business Research, 70, 432-440. https://doi.org/10.1016/j.jbusres.2016.06.019

Kozlenkova, I. V., Samaha, S. A., \& Palmatier, R. W. (2014). Resource-based theory in marketing. Journal of the Academy of Marketing Science, 42(1), 1-21. https://doi.org/10.1007/s11747-013-0336-7

Lillis, B., \& Lane, R. (2007). Auditing the strategic role of operations. International Journal of Management Reviews, 9(3), 191-210. https://doi.org/10.1111/j.1468-2370.2007.00209.x

Makadok, R. (2001). Toward a synthesis of the resource-based and dynamic-capability views of rent creation. Strategic Management Journal, 22(5), 387-401. https://doi.org/10.1002/smj.158

March, J. G., Sproull, L. S., \& Tamuz, M. (1991). Learning from samples of one or fewer. Organization Science, 2(1), 1-13. https://doi.org/10.1287/orsc.2.1.1

Miller, D., Eisenstat, R., \& Foote, N. (2002). Strategy from the inside out: Building capability-creating organizations. California Management Review, 44(3), 37-54. https://doi.org/10.2307/41166131 
Morgan, R. E., Katsikeas, C. S., \& Appiah-Adu, K. (1998). Market orientation and organizational learning capabilities. Journal of Marketing Management, 14(4), 353-381. https://doi.org/10.1362/026725798784959444

Nakata, C., \& Zhu, Z. (2006). Information technology and customer orientation: A study of direct, mediated, and interactive linkages. Journal of Marketing Management, 22(3-4), 319-354. https://doi.org/10.1362/026725706776861208

Ngo, L. V., \& O'Cass, A. (2012). Performance implications of market orientation, marketing resources, and marketing capabilities. Journal of Marketing Management, 28(1-2), 173-187. https://doi.org/10.1080/0267257X.2011.621443

Nonaka, I., Toyama, R., \& Konno, N. (2000). SECI, Ba and leadership: a unified model of dynamic knowledge creation. Long Range Planning, 33(1), 5-34. https://doi.org/10.1016/S0024-6301(99)00115-6

Ordanini, A., Parasuraman, A., \& Rubera, G. (2014). When the recipe is more important than the ingredients: A qualitative comparative analysis (QCA) of service innovation configurations. Journal of Service Research, 17(2), 134-149. https://doi.org/10.1177/1094670513513337

Pérez, L., Dos Santos Paulino, V., \& Cambra-Fierro, J. (2017). Taking advantage of disruptive innovation through changes in value networks: Insights from the space industry. Supply Chain Management: An International Journal, 22(2), 97-106. https://doi.org/10.1108/SCM-01-2017-0017

Qiu, T. (2012). Managing boundary-spanning marketing activities for supply-chain efficiency. Journal of Marketing Management, 28(9-10), 1114-1131. https://doi.org/10.1080/0267257X.2011.617709

Ramaswami, S. N., Srivastava, R. K., \& Bhargava, M. (2009). Market-based capabilities and financial performance of firms: insights into marketing's contribution to firm value. Journal of the Academy of Marketing Science, 37(2), 97-116. https://doi.org/10.1007/s11747-008-0120-2

Randall, R. M., Day, G., \& Moorman, C. (2013). Regaining customer relevance: The outside-in turnaround. Strategy \& Leadership, 41(4), 17-23. https://doi.org/10.1108/SL-04-2013-0021

Ravald, A., \& Grönroos, C. (1996). The value concept and relationship marketing. European Journal of Marketing, 30(29), 19-30. https://doi.org/10.1108/03090569610106626

Riezebos, R., \& Van der Grinten, J. (2012). Positioning the brand: an inside-out approach. New York: Routledge. https://doi.org/10.4324/9780203802489

Russell, S. (1999). Business Excellence: From outside in or inside out? Total Quality Management, 10(4-5), 697-703. https://doi.org/10.1080/0954412997712

Saeed, S., Yousafzai, S., Paladino, A., \& De Luca, L. M. (2015). Inside-out and outside-in orientations: A meta-analysis of orientation's effects on innovation and firm performance. Industrial Marketing Management, 47, 121-133. https://doi.org/10.1016/j.indmarman.2015.02.037

Schulz, D., Jonker, J., \& Faber, N. (2018). Outside-In Constructions of Organizational Legitimacy: Sensitizing the Influence of Evaluative Judgments Through Mass Self-Communication in Online Communities. International Journal of Communication, 12, 23.

Selznick, P. (2011). Leadership in administration: A sociological interpretation. New Orleans: Quid Pro Books.

Slotegraaf, R. J., \& Pauwels, K. (2008). The impact of brand equity and innovation on the long-term effectiveness of promotions. Journal of Marketing Research, 45(3), 293-306. https://doi.org/10.1509/jmkr.45.3.293

Spender, J.-C. (1996). Making knowledge the basis of a dynamic theory of the firm. Strategic Management Journal, 17(S2), 45-62. https://doi.org/10.1002/smj.4250171106

Srivastava, R. K., Fahey, L., \& Christensen, H. K. (2001). The resource-based view and marketing: The role of market-based assets in gaining competitive advantage. Journal of Management, 27(6), 777-802. https://doi.org/10.1177/014920630102700610

Srivastava, R. K., Shervani, T. A., \& Fahey, L. (1998). Market-based assets and shareholder value: A framework for analysis. The Journal of Marketing, 2-18. https://doi.org/10.1177/002224299806200102

Teece, D. J., Pisano, G., \& Shuen, A. (1997). Dynamic capabilities and strategic management. Strategic Management Journal, 18(7), 509-533. https://doi.org/10.1002/(SICI)1097-0266(199708)18:7<509::AID-SMJ882>3.0.CO;2-Z 
Tracey, M., Lim, J.-S., \& Vonderembse, M. A. (2005). The impact of supply-chain management capabilities on business performance. Supply Chain Management: An International Journal, 10(3), $179-191$. https://doi.org/10.1108/13598540510606232

Ulrich, D., \& Smallwood, N. (2007). Building a leadership brand. Harvard Business Review, 85(7/8), 92.

Urde, M., Baumgarth, C., \& Merrilees, B. (2013). Brand orientation and market orientation-From alternatives to synergy. Journal of Business Research, 66(1), 13-20. https://doi.org/10.1016/j.jbusres.2011.07.018

van Lakerveld, A., \& van Tulder, R. (2017). Managing the transition to sustainable supply chain management practices: Evidence from Dutch leader firms in Sub-Saharan Africa. Review of Social Economy, 75(3), 255-279. https://doi.org/10.1080/00346764.2017.1286033

Williamson, O. E. (1991). Strategizing, economizing, and economic organization. Strategic Management Journal, 12(S2), 75-94. https://doi.org/10.1002/smj.4250121007

Yamin, M., \& Kurt, Y. (2018). Revisiting the Uppsala internationalization model: Social network theory and overcoming the liability of outsidership. International Marketing Review, 35(1), 2-17. https://doi.org/10.1108/IMR-11-2014-0345

Yin, R. K. (2008). Case study research: Design and models. Los Angeles, CA: Sage Publications.

\section{Copyrights}

Copyright for this article is retained by the author, with first publication rights granted to the journal.

This is an open-access article distributed under the terms and conditions of the Creative Commons Attribution license (http://creativecommons.org/licenses/by/4.0/). 